\title{
Antineoplastic, Bio-Chemical, Cytotoxic and Antimicrobial Investigation on Synthesized Schiff Base Co(II) Ion Complex
}

\author{
Kudrat-E-Zahan $^{1, ~ *, ~ S a d d a m ~ H o s s a i n ~}{ }^{1}$, M. M. Haque ${ }^{1}$, Laila Arjuman Banu' ${ }^{1}$, M. A. Matin ${ }^{2}$, \\ Nur Amin Bitu ${ }^{1}$, Ahsan Habib ${ }^{1}$, Ashrafuzzaman ${ }^{1}$, Nayon Uddin ${ }^{1}$, M. S. Islam ${ }^{1}$ \\ ${ }^{1}$ Department of Chemistry, University of Rajshahi, Rajshahi, Bangladesh \\ ${ }^{2}$ Department of Materials Science and Engineering, University of Rajshahi, Rajshahi, Bangladesh
}

Email address:

kudrat.chem@ru.ac.bd (Kudrat-E-Zahan)

${ }^{*}$ Corresponding author

\section{To cite this article:}

Kudrat-E-Zahan, Saddam Hossain, M. M. Haque, Laila Arjuman Banu, M. A. Matin, Nur Amin Bitu, Ahsan Habib, Ashrafuzzaman, Nayon Uddin, M. S. Islam. Antineoplastic, Bio-Chemical, Cytotoxic and Antimicrobial Investigation on Synthesized Schiff Base Co(II) Ion Complex. Biochemistry and Molecular Biology. Vol. 4, No. 3, 2019, pp. 35-41. doi: 10.11648/j.bmb.20190403.11

Received: March 21, 2019; Accepted: May 31, 2019; Published: August 6, 2019

\begin{abstract}
Antibiotic resistance has been growing at an alarming rate and consequently the activity of antibiotics has dropped dramatically day by day. Metal complex [Co (SB) $(\mathrm{SCN})]$ (where, $\mathrm{SB}=2$-[(6-Amino-hexylimino)-methyl] phenol) have been reported for the purpose of searching new antimicrobial agents. The Schiff base and it's transition metal complex was characterized by means of several physiochemical and spectroscopic methods. Several biomedical toxicological properties of the complex has been determined by monitoring the parameters cell growth inhibition, survival time of tumour mice, timebody relation, causing of intraperitoneal cells and macrophages, alkaline phosphatase activity, haematological effect and biopsy of tumour. The synthesized Schiff base Co (II) complex was found to have anticancer and cytotoxic function.
\end{abstract}

Keywords: Transition Metal Complex, Antineoplastic, Bio-Chemical, Cytotoxic and Antimicrobial Studies

\section{Introduction}

Medicinal inorganic chemistry can exploit the unique properties of metal ions for the design of new drugs. This has, for instance, led to the clinical application of chemotherapeutic agents for cancer treatment. Although metals have long been used for medicinal purposes in a more or less empirical fashion [1], the potential of metal-based anticancer agents has only been fully realised and explored since the landmark discovery of the biological activity of cisplatin [2]. The use of cisplatin is, however, severely limited by its toxic side effects. This has spurred chemists to employ different strategies in the development of new metalbased anticancer agents with different mechanisms of action. Medicinal inorganic chemistry [3-5] is a field of increasing prominence as metal-based compounds offer possibilities for the design of therapeutic agents not readily available to organic compounds. The wide range of coordination numbers and geometries, accessible redox states, thermodynamic and kinetic characteristics, and the intrinsic properties of the cationic metal ion and ligand itself offer the medicinal chemist a wide spectrum of reactivities that can be exploited. Schiff base metal complexes constitute an essential class of compounds with various pharmaceutical activities including activity against several fungal and bacterial infections [6]. They have also been found to be active against HIV and tumour cells, and as good anti-tubercular, anti-inflammatory, anticoagulant and anticonvulsant for agents [7-9]. Large number of Schiff base compounds and their metal complexes have been synthesized and structurally characterized. The chemistry of Schiff base ligands and their metal complexes have attracted a lot of interest due to their facile synthesis and wide range of applications including antifungal, antibacterial, anticancer and catalytic fields [10-13].

Recently, we studied antineoplastic, bio-chemical, cytotoxic and antimicrobial activity of Schiff base $\mathrm{Cu}$ (II) ion 
Complexes [14]. In present study, Co (II) complex containing Schiff base ligand derived from 2-hydroxybenzaldehyde with 1, 6-diaminohexane, have been synthesized and characterized. In addition, antineoplastic, bio-chemical, cytotoxic, toxicity and for antimicrobial activities of the complex was studied.

\section{Experimental}

\subsection{Physical Measurement}

The physical measurements were done according to literature method [14]. All other chemicals were commercial products and were used as supplied.

\subsection{Preparation of Schiff Base,}

\section{2-[(6-Amino-Hexylimino)-Methyl] Phenol (SB)}

Salicylaldehyde $(0.61 \mathrm{~g}, \quad 0.005 \mathrm{~mol})$ in absolute methanol $(20 \mathrm{~mL})$ was added to an ethanolic solution $(25$ $\mathrm{mL})$ of 1,6 diaminohexane $(0.58 \mathrm{~g}, 0.005 \mathrm{~mol})$. The mixture was heated to reduce the volume to $20 \mathrm{~mL}$ and then it was cooled in an ice-bath. The black crystalline product was filtered and washed with hot ethanol and dried in vacuum over $\mathrm{P}_{4} \mathrm{O}_{10}$. The structure of Schiff base (SB-2) was shown in figure 1.

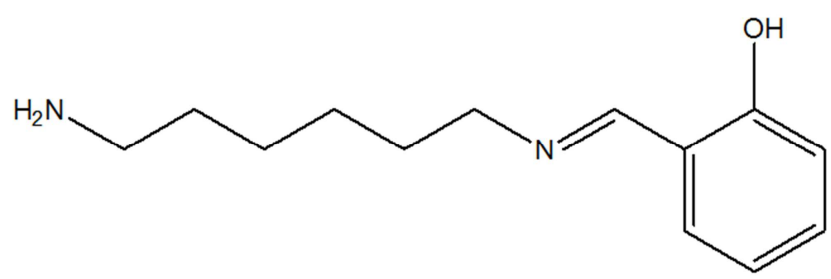

Figure 1. 2-[(6-Amino-hexylimino)-methyl] phenol (SB).

\subsection{Preparation of $[\mathrm{Co}(\mathrm{SB})(\mathrm{SCN})]$}

$25 \mathrm{~mL}$ of an ethanolic solution of $\mathrm{CoCl}_{2} \cdot 6 \mathrm{H}_{2} \mathrm{O}(0.005$ mol) was added to $30 \mathrm{~mL}$ of an ethanolic solution of the above prepared Schiff base (1.05 g, $0.005 \mathrm{~mol})$. Then 20 $\mathrm{mL}$ of an ethanolic solution of potassium thiocyanate $(0.005 \mathrm{~mol})$ was added to the metal salt-Schiff base solution. It was boiled on a water-bath for 5 minutes and after that it was cooled. The colored complex was separated and washed with hot ethanol.

\section{Results and Discussion}

\subsection{Elemental Analysis and Conductivity Measurement}

The analytical data and their physical properties of the complex are given in Table 1. The molar conductance in DMSO indicates that the complex is $1: 1$ electrolyte $[15,16]$.

\subsection{IR Studies}

The Schiff base, 2-[(6-Amino-hexylimino)-methyl] phenol (SB) is potentially tridentate, the available coordination sites being the amino nitrogen, methane nitrogen and the oxo anion. The free ligand shows characteristic bands at $3500 \mathrm{~cm}^{-}$ ${ }^{1} \mathrm{v}(\mathrm{OH}), 3420 \mathrm{~cm}^{-1}, 3480 \mathrm{~cm}^{-1} \mathrm{v}\left(\mathrm{NH}_{2}\right)$ and $1613 \mathrm{~cm}^{-1} \mathrm{v}$ $(\mathrm{C}=\mathrm{N})$. In the complexes, a broad band appears at 3400-3600 $\mathrm{cm}^{-1}$, in which $\mathrm{v}\left(\mathrm{NH}_{2}\right)$ bands of the complexes are probably hidden. The $\mathrm{NH}_{2}$ complexation is afforded from the appearance of $\mathrm{v}(\mathrm{M}-\mathrm{N})$ modes at $400-470 \mathrm{~cm}^{-1}$ in the complexes. We believe that the ligand deprotonates at the $\mathrm{OH}$ end providing an oxo coordination, as is evident from the $\mathrm{v}$ (M-O) bands at $435 \mathrm{~cm}^{-1}$ in the complex. The $\mathrm{v}(\mathrm{C}=\mathrm{N})$ band observed at $1613 \mathrm{~cm}^{-1}$ in the free ligand is shifted to 1600 $\mathrm{cm}^{-1}$ indicating coordination by the methane nitrogen. The ambidentate thiocyanate ligand can coordinate either through the nitrogen or through the sulfur depending on the size of the metal ions. In general, the $\mathrm{v}(\mathrm{C}=\mathrm{N})$ modes appear at lower frequencies in $\mathrm{M}-\mathrm{N}=\mathrm{C}=\mathrm{S}$ complexes than those of $\mathrm{M}-\mathrm{S}-\mathrm{C}=\mathrm{N}$ complexes. The complex also display $\mathrm{v}(\mathrm{CN})$ at $2053 \mathrm{~cm}^{-1}$ characteristic of S-bonded thiocyanato moieties. In Pearson's terminology, these are soft acids. The $\mathrm{v}(\mathrm{CS})$ modes appear at lower frequencies in the $\mathrm{M}-\mathrm{S}-\mathrm{C}=\mathrm{N}$ complex than those of in the $\mathrm{M}-\mathrm{N}=\mathrm{C}=\mathrm{S}$ complex. Complex exhibit $\mathrm{v}(\mathrm{CS})$ at 738-762 $\mathrm{cm}^{-1}$ characteristic of $\mathrm{M}-\mathrm{S}-\mathrm{C}=\mathrm{N}$ bonding sequence. This is further apparent from the $\mathrm{v}(\mathrm{M}-\mathrm{S})$ modes at $410 \mathrm{~cm}^{-1}$ in the far IR spectra of the complex [17-23].

\subsection{Magnetic Moment and Electronic Spectra}

The complex is paramagnetic and show magnetic moment 1.93. In electronic spectra three bands were observed at $15,350,19,450$ and $22,172 \mathrm{~cm}^{-1}$ corresponding to the transitions $\left[{ }^{4} \mathrm{~T}_{1 \mathrm{~g}} \rightarrow{ }^{4} \mathrm{~T}_{2 \mathrm{~g}}(\mathrm{~F})\right],\left[{ }^{4} \mathrm{~T}_{1 \mathrm{~g}} \rightarrow{ }^{4} \mathrm{~A}_{2 \mathrm{~g}}(\mathrm{~F})\right],\left[{ }^{4} \mathrm{~T}_{1 \mathrm{~g}} \rightarrow{ }^{4} \mathrm{~T}_{1 \mathrm{~g}}(\mathrm{P})\right]$ respectively for compound which are in good agreement with tetrahedral geometry [23-26]. The values found are given in parenthesis.

Table 1. Analytical Data and Physical Properties.

\begin{tabular}{|c|c|c|c|c|c|c|c|c|}
\hline Complex & Colour & $\begin{array}{l}\text { Melting } \\
\text { point }\left({ }^{\circ} \mathrm{C}\right)\end{array}$ & $\% \mathbf{M}$ & $\% \mathrm{C}$ & $\% \mathbf{H}$ & $\% \mathrm{~N}$ & $\begin{array}{l}\text { Molar conductance } \\
\left(\mathrm{Ohm}^{1} \mathrm{~cm}^{2} \mathrm{~mol}^{-1}\right)\end{array}$ & $\begin{array}{l}\text { Magnetic moment } \\
\text { M }_{\text {eff }}(\text { B.M) } \\
\end{array}$ \\
\hline $\begin{array}{l}{\left[\mathrm{Co}\left(\mathrm{C}_{13} \mathrm{H}_{19} \mathrm{~N}_{2}\right)\right.} \\
(\mathrm{SCN})]\end{array}$ & Black & 164 & $\begin{array}{l}17.74 \\
(18.65) \\
\end{array}$ & $\begin{array}{l}46.93 \\
(49.34) \\
\end{array}$ & $\begin{array}{l}5.31 \\
(5.58) \\
\end{array}$ & $\begin{array}{l}11.73 \\
(12.33) \\
\end{array}$ & 30 & 1.93 \\
\hline
\end{tabular}

\section{Antineoplastic Activity of the Test Complex}

\subsection{The Effect of Test Compound and Bleomycin on Ehrlich Ascites Carcinoma (EAC) Cell Growth Inhibition}

Treatment with test complex resulting in maximum cell growth inhibition on complex as evident from $95.52 \%$, reduction of tumour cell which was found to be equivalent to standard or nearly standard antitumour agent bleomycin which shows cell growth inhibition is $94.90 \%$. The results are shown in Table 2 . 
Table 2. The effect of test compound and bleomycin on EAC cell growth inhibition.

\begin{tabular}{|c|c|c|c|c|}
\hline Experiment & Drugs & Dose & $\begin{array}{l}\text { No. of EAC cells/mouse on } 5^{\text {th }} \text { day after tumour (EAC) cell } \\
\text { inoculation }\end{array}$ & $\%$ of cell growth inhibition \\
\hline EAC & & & $(9.61 \pm 1.63) \times 10^{7}$ & \\
\hline EAC + Bleomycin & & $0.3 \mathrm{mg} / \mathrm{kg}$ & $(0.49 \pm .77) \times 10^{7}$ & 94.90 \\
\hline$\left[\mathrm{Co}\left(\mathrm{C}_{13} \mathrm{H}_{19} \mathrm{~N}_{2}\right)(\mathrm{SCN})\right]$ & Synthetic & $20 \mathrm{mg} / \mathrm{kg}$ & $(0.43 \pm 0.67) \times 10^{7}$ & 95.52 \\
\hline
\end{tabular}

\subsection{Effect of Test Complex on Survival Time of Ehrlich Ascites Carcinoma (EAC) Cell Bearing Mice}

It was found that treatment of tumour induced test animals was the complex resulting the increase of life span $40.38 \%$, respectively when compared to control mice (life span 21.37 days). It was noticed that the anticancer antibiotic bleomycin increases the life span by $87.17 \%$ when compared to control. The results are shown in Table 3 .

Table 3. The Effect of test compound on survival time of EAC cell bearing mice.

\begin{tabular}{|c|c|c|c|c|}
\hline Name of Experiment & Drugs & Dose & Mean survival time & $\%$ increase life span \\
\hline Control (EAC bearing mice) & & & $(21 \pm 1.7)$ & \\
\hline EAC + Bleomycin & & $0.3 \mathrm{mg} / \mathrm{kg}$ & $40 \pm 1.2$ & 87.17 \\
\hline$\left[\mathrm{Co}\left(\mathrm{C}_{13} \mathrm{H}_{19} \mathrm{~N}_{2}\right)(\mathrm{SCN})\right]$ & Synthetic & $20 \mathrm{mg} / \mathrm{kg}$ & $30 \pm 21$ & 40.38 \\
\hline
\end{tabular}

\subsection{Effect of Test Complex and Bleomycin on Average Tumour Weight}

Treatement of the test animals with test complex, previously inculated with EAC cells, resulted in the inhibition of tumour growth. In case of treated group the body weight was growing slowly and by $54.77 \%$ more less in complex compaired to control group after 20 days of tumour inculation. But in case of bleomycin, this value is $52.63 \%$ compaired to control group. DMSO does not show any change of body weight compaired to control group. The results are shown in Table 4.

Table 4. The Effect of test complex on survival time of EAC cell bearing mice.

\begin{tabular}{lllll}
\hline Days & Control (EAC) & Bleomycin (0.3 mg/kgi.p) & DMSO 25 $\mathbf{~ m g} / \mathbf{k g}$ & $\left.\left[\mathbf{C o}_{(\mathbf{1 3}} \mathbf{C}_{\mathbf{1 9}} \mathbf{N}_{\mathbf{2}}\right)(\mathbf{S C N})\right] \mathbf{~ 2 0 ~} \mathbf{~ m g} / \mathbf{~ k g}$ \\
\hline 0 & 00 & 00 & 00 & 00 \\
2 & $0.77 \pm .37$ & $0.57 \pm .17$ & $0.76 \pm .38$ & $0.52 \pm .31$ \\
4 & $0.98 \pm .43$ & $0.75 \pm .22$ & $0.97 \pm .63$ & $0.71 \pm .23$ \\
6 & $1.30 \pm .27$ & $1.10 \pm .24$ & $1.31 \pm .33$ & $1.02 \pm .17$ \\
8 & $1.54 \pm .32$ & $1.24 \pm .14$ & $1.57 \pm .23$ & $1.18 \pm .12$ \\
10 & $1.78 \pm .18$ & $1.44 \pm .30$ & $1.76 \pm .16$ & $1.23 \pm .26$ \\
12 & $2.13 \pm .17$ & $1.63 \pm .16$ & $2.14 \pm .17$ & $1.41 \pm .76$ \\
14 & $2.55 \pm .67$ & $1.80 \pm .23$ & $2.55 \pm .63$ & $1.64 \pm .23$ \\
16 & $3.94 \pm .55$ & $2.05 \pm .27$ & $3.93 \pm .53$ & $1.89 \pm .14$ \\
18 & $4.44 \pm .43$ & $2.20 \pm .15$ & $4.40 \pm .42$ & $2.06 \pm .22$ \\
20 & $5.13 \pm .63$ & $2.43 \pm .11$ & $5.14 \pm .62$ & $2.32 \pm .13$ \\
\hline
\end{tabular}

\subsection{The Effect of Test Complex on Heamatological Parameters in Normal and Tumour Bearing Mice}

Hematological parameters were studied in normal and tumour bearing mice. All were treated with test complexes for 12 days of tumour transplantation and after 12 days they were sacrificed and blood was collected for heamatological examination. Numbers of mice were four. Results were shown in mean \pm SEM (standard error of mean) and compaired with normal (without EAC bearing mice) and control (EAC bearing mice) group as shown in Table 5. Their growth of tumour in mice induced by EAC cells effect in acute condition as indicated by the significant decrease of the $\mathrm{Hb} \%$ when compaired to normal test animals under similar condition on day 12. The total white blood cell (WBC) count was also markedly decreased in the control group. In differential count of WBC, lymphocyte count was also found to be decreased and neutrophil count was increased on day 12 of tumour inoculation but no significant changes was observed in monocyte count on day 12 of the tumour inoculation as compaired with normal mice. Effect of test complex on haematological parameters of normal mice was also determined. No significant effect was found.

Table 5. The effect of test complex on heamatological parameters in normal and tumour bearing mice.

\begin{tabular}{lllllll}
\hline Name of experiment & HB level g/dl & RBC cell/mL & WBC(TC) cell/mL & Lymphocyte\% & Neutrophil\% & Monocyte\% \\
\hline Normal mice & $13.65 \pm .4$ & $(7.96 \pm .57) \times 10^{9}$ & $(6.35 \pm .26) \times 10^{6}$ & $71.25 \pm .91$ & $19.19 \pm .28$ & $8.93 \pm .23$ \\
N + Complex & $12.50 \pm .22$ & $(6.89 \pm .14) \times 10^{9}$ & $(9.14 \pm .22) \times 10^{6}$ & $75.20 \pm .45$ & $22.14 \pm .21$ & $2.23 \pm .11$ \\
EAC (mice) & $7.11 \pm .23$ & $(2.40 \pm .10) \times 10^{9}$ & $(25.63 \pm .18) \times 10^{6}$ & $43.36 \pm .43$ & $38.23 \pm .37$ & $10 \pm .28$ \\
EAC + Complex & $11.92 \pm .67$ & $(7.10 \pm .66) \times 10^{9}$ & $(10.72 \pm 2.3) \times 10^{6}$ & $63.40 \pm 2.70$ & $32.46 \pm 1.88$ & $4.10 \pm 1.16$ \\
\hline
\end{tabular}




\subsection{The Effect of Test Complex on Serum Alkaline Phosphate Activity}

Serum alkaline phosphatase was studied in normal and tumour bearing mice. Tumour bearing mice were treated with test complexes for 5 days of tumour transplantation and after 5 days they were sacrificed and blood was collected for determination of serum phosphatase. Serum alkaline phosphatase activity level in tumour bearing was decreased due to tumourogenesis when compared to the normal. Treatment with the test compound restore the enzyme activity towards normal significantly after the treatment as shown in Table 6. In normal mice test compound showed increase of serum alkaline phosphatase activity.

Table 6. The effect of test complex on serum alkaline phosphate activity determined on day 12 of tumor inoculation in normal and tumour bearing mice.

\begin{tabular}{llll}
\hline Name of Experiment & $\begin{array}{l}\text { ALKP activity }(\boldsymbol{\mu m o l} \text { of PNPP } \\
\text { hydrolyzed/min/mL/serum }\end{array}$ & Name of Experiment & $\begin{array}{l}\text { ALKP activity }(\boldsymbol{\mu m o l ~ o f ~ P N P P ~} \\
\text { hydrolyzed/min/mL/serum }\end{array}$ \\
\hline EAC & $(8.56 \pm .31) \times 10^{-3}$ & Normal value & $(28.33 \pm .71) \times 10^{-3}$ \\
EAC + DMSO & $(28.96 \pm .21) \times 10^{-3}$ & DMSO & $(29.13 \pm .14) \times 10^{-3}$ \\
EAC + Complex & $(2.46 \pm .88) \times 10^{-3}$ & $\mathrm{~N}+\mathrm{B}$ & $(40.90 \pm .23) \times 10^{-3}$ \\
\hline
\end{tabular}

\subsection{Effect of Test Complex on the Enhancement of Normal Peritoneal Cells and Macrophages of Life}

Treatment with the test complex did not show any effect on the enhancement of number of peritoneal cells but the number of macrophages increases as shown in Table 7.

Table 7. The effect of test complex on the enhancement of normal peritoneal cells and macrophages of life.

\begin{tabular}{llll}
\hline Name of the Experiment & $\begin{array}{l}\text { Dose } \\
\mathbf{m g} / \mathbf{k g}\end{array}$ & $\begin{array}{l}\text { Total peritoneal macrophage }\left(\mathbf{x} / \mathbf{1 0}^{\mathbf{6}} \text { cells }\right) / \text { mouse } \\
\text { Mean } \pm \text { SEM }\end{array}$ & $\begin{array}{l}\text { Total peritoneal cells }\left(\mathbf{x} / \mathbf{1 0}^{6}\right) / \mathbf{m o u s e} \\
\text { Mean } \pm \text { SEM }\end{array}$ \\
\hline Normal & Tap water & $3.23 \pm 2.0$ & $23.76 \pm .321$ \\
{$\left[\mathrm{Co}\left(\mathrm{C}_{13} \mathrm{H}_{19} \mathrm{~N}_{2}\right)(\mathrm{SCN})\right]$} & 20 & $6.53 \pm .10$ & $23.22 \pm .52$ \\
\hline
\end{tabular}

\subsection{The Effect of Test Complex on Generation of MDA by Lipid Peroxidation in Serum of Normal Mice}

Table 8. The effect of test complex on generation of MDA by lipid peroxidation in serum of normal mice.

\begin{tabular}{ll}
\hline Name of the Experiment & mmol MDA/ mL serum \\
\hline Normal mice $($ control $)$ & $6.71 \pm 0.32$ \\
{$[\mathrm{Co}(\mathrm{C} 13 \mathrm{H} 19 \mathrm{~N} 2)(\mathrm{SCN})]$} & $12.88 \pm .44$ \\
\hline
\end{tabular}

Animals were treated with test complex for 4 consecutive days. Serums from mice were collected on day 5 and malondialdehyde (MDA) concentration was measured. The dose of the test complexes $\mathrm{A}$ and $\mathrm{B}$ was $16 \mathrm{mg} / \mathrm{kg}$ and $20 \mathrm{mg} / \mathrm{kg}$ respectively. Effect of test complex on normal mice showed that there was markedly increase in MDA, which indicates that there was release for free radical. The obtained data are shown in Table 8.

\subsection{Histopathological Effect of Test Complex}

Ehrlich Ascites Carcinoma (EAC) cell induced tumour at the site of injection was very prominent and showed fast growth, increased in size, bulging out in skin. The histological feature shows necrosis at the center and viable growing cells in the periphery. Some inflammatory reaction lymphocytic in nature with reduction of hair follicle was observed. The number of mitosis was observed which increases greatly. When treated with test compound and bleomycin growth rate tumour is reduced, inflammatory reaction increases in some extent (Table 9). Necrotic area is increased and hair follicle appears their normal appearance.

Table 9. Histopathological effect of test complex.

\begin{tabular}{lllll}
\hline \multirow{2}{*}{ Name of the Experiment } & Observation & & \\
\cline { 2 - 4 } & Size & Number of Lymphocytes & Necrotic area & Inflammatory area \\
\hline EAC & $\uparrow \uparrow \uparrow$ & $\downarrow \downarrow \downarrow$ & & \\
{$[\mathrm{Co}(\mathrm{C} 13 \mathrm{H} 19 \mathrm{~N} 2)(\mathrm{SCN})]$} & $\downarrow \downarrow \downarrow$ & $\uparrow \uparrow \uparrow$ & $\uparrow \uparrow \uparrow$ & $\uparrow \uparrow \uparrow$ \\
Bleomycin & $\downarrow \downarrow \downarrow$ & $\uparrow \uparrow \uparrow$ & $\uparrow \uparrow \uparrow$ & $\uparrow \uparrow \uparrow$ \\
\hline
\end{tabular}

Where,

$\uparrow=$ increase, $\uparrow \uparrow=$ moderately increase, $\uparrow \uparrow \uparrow=$ greatly increase

$\downarrow=$ decrease, $\downarrow \downarrow=$ moderately decrease, $\downarrow \downarrow \downarrow=$ greatly decrease

\subsection{Effect of Test Complex on Total Protein in Peritoneal Fluid}

Inculation of Ehrlich ascites carcinoma (EAC) cell in peritonenal cavity causes of accumulation of fluid which is rich in protein. But when treated with test complexes, the protein contain in the peritoneal fluid is reduced and fluids accumulate in the peritoneal cavity very slowly (Table 10). 
Table 10. Effect of test compound on total protein in peritoneal fluid.

\begin{tabular}{lll}
\hline Name of the Complex & Dose $(\mathbf{m g} / \mathbf{k g})$ & $\begin{array}{l}\text { Total protein } \\
\mathbf{m g} / \mathbf{m L}, \mathbf{P . F}, \text { mean } \pm \text { SEM }\end{array}$ \\
\hline Control (EAC) & Tap water & $174.73 \pm 2.81$ \\
{$[\mathrm{Co}(\mathrm{C} 13 \mathrm{H} 19 \mathrm{~N} 2)(\mathrm{SCN})]$} & 20 & $163.51 \pm 4.20$ \\
\hline
\end{tabular}

\section{Antifungal Activity of the Test Compounds}

The antifungal activity of the test complex against different fungi was investigated by using the doses of $80 \mu \mathrm{g} /$ disc, where standard antibiotic disc of Nystatin $(45 \mu \mathrm{g} /$ disc $)$ was used for comparison purpose. The diameter was evaluated $10 \mathrm{~mm}$ against tinea pedis, $13 \mathrm{~mm}$ against asperigillus niger, $10 \mathrm{~mm}$ against collectrichum $\mathrm{sp}$. for test complex whereas diameter of zone of inhibition of Nystatin was found to be $18 \mathrm{~mm}, 28 \mathrm{~mm}, 20 \mathrm{~mm}$ respectively against those organism. The results of the antifungal activity (zone of inhibition) of the test complex against respective fungai are presented in Table 11. The minimum inhibitory concentration of the test complex are $64 \mu \mathrm{g} /$ disc, $64 \mu \mathrm{g} /$ disc, $80 \mu \mathrm{g} / \mathrm{disc}$ against tinea pedis, asperigillus niger and collectrichum respectively.

Table 11. Zone of inhibition of antifungal activity of test complex.

\begin{tabular}{lll}
\hline \multirow{2}{*}{ Test fungus } & $\begin{array}{l}\text { Diameter of zone of inhibition } \\
(\mathbf{m m}) \text { of test complexes }\end{array}$ & $\begin{array}{l}\text { Nystatin } \\
(\mathbf{4 5} \boldsymbol{\mu g} / \mathbf{~ d i s c})\end{array}$ \\
\cline { 2 - 3 } & $[\mathbf{C o}(\mathbf{C 1 3 H 1 9 N 2}) \mathbf{S C N})]$ & \\
\hline Tinea pedis & 10 & 18 \\
(Tricophyton) & & 28 \\
Asperigillus niger & 13 & 20 \\
Conlitotrium sp. & 10 & \\
\hline
\end{tabular}

\section{Antibacterial Activity of the Test Complexes}

The antibacterial activity of the test complex was determined by using the dose of $80 \mu \mathrm{g} /$ disc. The results of antibacterial activity measured in terms of zone of inhibition is shown in Table 12. The complexes showed minimum sensitivity against the following number of both gram positive and gram negative bacteria and the results were compared with antibiotic disc of kanamycin.

Table 12. Result of antibacterial activity of test complex.

\begin{tabular}{lll}
\hline Test Bacteria & $\begin{array}{l}\text { Diameter of Zone of } \\
\text { inhibition }(\mathbf{m m}) \text { of } \\
\text { test compound }\end{array}$ & $\begin{array}{l}\text { Kanamycin } \\
\text { (Ts/25 } \boldsymbol{\mu g} \text { /disc) }\end{array}$ \\
\hline Bacillus subtilis & 9 & 16 \\
Streptococcus- $\beta$-haemolytica & 10 & 25 \\
Escharicia coli & 10 & 17 \\
Sarcina lutea & 12 & 19 \\
Klebsella & 9 & 17 \\
Shigella flexeri & 10 & 14 \\
Shigella voydii & 10 & 24 \\
Shigella dysenteriac & 14 & 14 \\
Pseudomonas aeruginosa & 8 & 13 \\
\hline
\end{tabular}

\section{Toxicity of the Test Complex}

The toxicity of the test complexes were determined by using the dose of $10 \mathrm{mg} / \mathrm{kg}$. Mature male rats weighing $100-$ $120 \mathrm{~g}$ were used through the study. Animals were maintained in standard laboratory conditions. Treatment of the experimental animals with the text complexes resulted in a decrease in the amount of hemoglobin when compared with the control animals. Total count of WBC was significantly altered when treated with test complexes as shown in Table 13. In differential count of $\mathrm{WBC}$, lymphocytes and platelet count were significantly increased as compared to the control group. Effect of text complex on some biochemical parameters in normal rats are shown in Table 14. In this study it was found that treatment with the test complex with the test doses alter the all biochemical parameters compared to the normal control group. So the test complexes are hepatotoxic as well as nephrotoxic.

Table 13. Effect of test complex on haematological parameters in rats.

\begin{tabular}{|c|c|c|c|c|c|c|}
\hline Name of experiment & $\mathrm{WBC}\left(\right.$ cells $\left./ \mathrm{mm}^{3}\right)$ & $\mathrm{Hb}(\mathrm{g} / \mathrm{dl})$ & Lymphocyte (\%) & Neutrophil\% & Monocyte\% & Platelet (cell/ml) \\
\hline Normal & 8400 & $12.6 \pm 0.05$ & $58.15 \pm 1.92$ & $35.15 \pm 1.58$ & $4.25 \pm 0.43$ & 315000 \\
\hline DMSO & 5200 & $12.1 \pm 1.10$ & $62 \pm 2.03$ & $34 \pm 02$ & $4 \pm 1.03$ & 420000 \\
\hline Complex & 6000 & $10.3 \pm 1.00$ & $61 \pm 3.00$ & $36 \pm 02$ & $3 \pm 1.00$ & 360000 \\
\hline
\end{tabular}

The number of rat in each group were 4 . Results were shown in mean \pm Standard Error Mean

Table 14. Effect of test complex on Biochemical parameters in rats.

\begin{tabular}{|c|c|c|c|c|c|c|c|c|c|}
\hline & $\begin{array}{l}\text { Blood glucose } \\
\text { (mg/dl blood) }\end{array}$ & $\begin{array}{l}\text { Serum } \\
\text { cholesterol } \\
\text { (mg/dl serum) }\end{array}$ & $\begin{array}{l}\text { Serum alkaline } \\
\text { phosphatase } \\
\text { U/L }\end{array}$ & $\begin{array}{l}\text { Serum total } \\
\text { protein }(\mathrm{g} / 100 \\
\text { ml serum) } \\
\end{array}$ & $\begin{array}{l}\text { Serum Creatinine } \\
\text { (mg/dl of blood) }\end{array}$ & $\begin{array}{l}\text { Blood Urea } \\
(\mathrm{mg} / \mathrm{dl})\end{array}$ & $\begin{array}{l}\text { ATL } \\
(\mathbf{U} / \mathbf{L})\end{array}$ & $\operatorname{AST}(\mathbf{U} / \mathbf{L})$ & $\begin{array}{l}\text { Serum } \\
\text { bilirubin } \\
(\mathrm{mg} / \mathrm{dl})\end{array}$ \\
\hline Normal & $104 \pm 1.63$ & $67.09 \pm 0.84$ & $78 \pm 4.15$ & $6.6 \pm .02$ & $1.09 \pm 0.16$ & $17.80 \pm 2.4$ & $25.4 \pm 2.2$ & $60.76 \pm 4.7$ & $0.34 \pm 0.11$ \\
\hline Complex & $69 \pm 3.2$ & $32 \pm 1.3$ & $144 \pm 3.3$ & $3.6 \pm 2.2$ & $5.7 \pm 1.1$ & $42 \pm 2.1$ & $186 \pm 5.5$ & $132 \pm 3.3$ & $6.8 \pm 2.2$ \\
\hline DMSO & $93 \pm 2$ & $63 \pm 4.1$ & $83 \pm 3.6$ & $5.5 \pm 1.5$ & $1.1 \pm 0.06$ & $41 \pm 2$ & $39 \pm 4$ & $89 \pm 3$ & $0.4 \pm 0.1$ \\
\hline
\end{tabular}

The number of rat in each group were 4 . Results were shown in mean \pm Standard Error Mean, ALT $=$ Alanine aminotransferase, AST $=$ Aspartate aminotransferase 


\section{Conclusion}

Study on antitumor activity in EAC cell bearing mice revealed that treatment with test complex prohibited the increase in body weight as mentioned and increase the life span in animals. The cytotoxic potency showed as significant reduction in the number of EAC cells and their viability support these data. However, our results on EAC cell count and viability after treatment with test complex are comparable to the effect of bleomycin observed in present study. Test complex also increased the concentration of MDA in blood and reduced the amount of protein. In addition, transition metal complex are capable of generating free radicals. Thus, it is suggested that it has anticancer or cytotoxic function to be associated with the increase in the load of free radicals. Furthermore, supported by the histopathological investigation on the tumour which showed a retardation of tumour growth, increase the necrotic and inflammatory area and increased their follicles, we definitely say that the test complex possess cytotoxic property. Antimicrobial activity of the test complex showed significant antimicrobial activity when compared to control. This antimicrobial property was correlate with anti-cancer property because microorganism possesses some criteria which are same. Toxicological studies reveal that the test complex is much more toxic to liver and kidney. This altered all biochemical parameters of rat blood. The exact mode of action of test complex is not known to us. Further investigation is appreciated to investigate detailed mechanism of action and their effect in serum electrolyte before any clinical use, especially of the effective doses.

\section{Conflict of Interests}

The authors declare that there is no conflict of interests regarding the publication of this paper

\section{Acknowledgements}

The authors are thankful to the Chairman, Department of Chemistry, Rajshahi University, Rajshahi, Bangladesh for the laboratory facilities and Dean, Faculty of Science, Rajshahi University, Rajshahi, Bangladesh for financial support.

\section{References}

[1] Thompson KH, Orvig C., Metal complexes in medicinal chemistry: new vistas and challenges in drug design. Dalton Trans. 2006, 6: 761-764.

[2] Jung Y, Lippard SJ. Direct cellular responses to platinuminduced DNA damage. Chem Rev., 2007, 107: 1387-1407.

[3] Hambley TW. Developing new metal-based therapeutics: challenges and opportunities. Dalton Trans. 2007, 43: 49294937.

[4] Orvig C, Abrams MJ, Medicinal inorganic chemistry: introduction. Chem Rev. 1999, 99: 2201-2203.

[5] Guo Z, Sadler PJ., Metals in Medicine. Angew Chem Int Ed. 1999, 38: 1512-1531.

[6] A. Faizul, S. Satendra, L. K. Sukhbir. P. Om. Synthesis of Schiff bases of naphtha [1, 2-d] thiazol-2-amine and metal complexes of 2- (2'-hydroxy) benzyli deneamino naphtha thiazole as potential antimicrobial agents. J. Zhejiang Univ Sci. 2007, 8 (6): 446-452.

[7] G. U. Maass, B. Koenig, U. Leser, B. Mueller, R. Goody, B. Pfatt, Viral resistance to the thiazole isoindolinones, a new class NNRTI of HIV-1 reverse transcriptase. Antimicrob Agents Chemother. 37 (12): 1993, 2612-2617.

[8] Geronikaki, D. Hadjipavlou-Litina, M. Amourgianou. Novel thiazolyl, thiazolinyl and benzothiazolyl, Schiff bases: a possible lipoxygenase's inhibitors and anti-inflammatory agents. IL Farmaco. 2003, 58 (7): 489-495.

[9] M. Malathy, R. Rajavel, Copper (II) complexes as in vitro anticancer agents against human breast cancer mcf-7 cell line: a review. European J. of Biomed. and Pharmaceutical sciences. 2015, 2 (3): 177-200.

[10] C. Jayabalakrishnan, R. Karvembu, K. Natarajan, Catalytic and antimicrobial activities of new ruthenium (II) unsymmetrical Schiff base complexes. Trans. Met. Chem. 2002, 27: 790-794.

[11] R. Prabhakaran, A. Geetha, M. Thilagavathi, R. Karvembu, V. Krishnan, H. Bertagnolli, K. Natarajan, Synthesis, characterization, EXAFS investigation and antibacterial activities of new $\mathrm{Ru}$ (III) complexes containing tetradentate Schiff base complexes. J. Inorg. Biochem. 2004, 98: 21312140 .

[12] K. P. Balasubramanian, R. Karvembu, R. Prabhakaran, V. Chinnusamy, K. Natarajan. Synthesis, spectral, catalytic and antimicrobial studies of $\mathrm{PPh}_{3} / \mathrm{AsPh}_{3}$ complexes of $\mathrm{Ru}$ (III) with dibasic tridentate $\mathrm{O}, \mathrm{N}, \mathrm{S}$ donor ligands. Spectrochim. Acta Part A. 2007, 68: 50-54.

[13] S. A. Sadeek, M. S. Refat, Preparation and Characterization of Tin (II) Complexes with Isomeric Series of Schiff Bases as Ligands. J. Korean Chem. Soc., 2006, 50 (2): 107-115.

[14] M. M. Haque, Md. Kudrat-E-Zahan, Laila Arjuman Banu, Md. Shariful Islam and M. S. Islam, synthesis and Characterization with Antineoplastic, Bio-Chemical, Cytotoxic and Antimicrobial studies of schiff base $\mathrm{Cu}$ (II) ion Complexes. Bioinorganic Chemistry and Applications, 2015, Article ID 923087, p. 7.

[15] W. J. Geary, The use of conductivity measurements in organic solvents for the characterisation of coordination compounds. Coordination Chemistry Reviews, 1971, 7 (1): 81-122.

[16] Md. Saddam Hossain, Md. Ashraful Islam, C. M. Zakaria, M. M. Haque, Md. Abdul Mannan, Md. Kudrat-E-Zahan, Synthesis, Spectral and Thermal Characterization with Antimicrobial Studies on Mn (II), Fe (II), Co (II) and Sn (II) Complexes of Tridentate N, O Coordinating Novel Schiff Base Ligand. J. Chem. Bio. Phy. Sci, 2016, 7 (4): 041-052.

[17] Md. Saddam Hossain, C. M. Zakaria, M. K. Zahan, Synthesis and Characterization with Antimicrobial Activity studies on some Transition metal complexes of N, O donor novel Schiff base ligand. J. Sci. Res. 2017, 9 (2): 209-218. 
[18] Md. Shiraj-U-Ddaula, Md. Anarul Islam, Shejuty aktar, Md. Khairul Islam, Md. Abdul Alim Al-Bari, Md. Masuqul Haque and Md. Kudrat-E-Zahan, Synthesis, Characterization and Antimicrobial Activity of Cd (II), Ni (II), Co (II) and Zr (IV) Metal Complexes of Schiff Base Ligand Derived from Diethylenetriamine and Isatin. Asian J. Research Chem. 2014, 7 (7): 619-621.

[19] Ahmed Jasim M. Al-Karawi, Synthesis and characterization of a new $\mathrm{N}_{2} \mathrm{~S}_{2}$ Schiff base ligand and its complexes with nickel (II), copper (II) and cadmium (II) including the kinetics of complex formation. Transition Met Chem, 2009, 34: 891-897.

[20] Md. Saddam Hossain, C. M. Zakaria, Md. Kudrat-E-Zahan, Synthesis, Spectral and Thermal Characterization of novel $\mathrm{Cu}$ (II) Complexes with Two New Schiff Base Ligand towards Potential Biological Application. Der Chemica Sinica, 2017, 8 (3): 380-392.

[21] Md. Saddam Hossain, Shudeepta Sarker, A. S. M. Elias Shaheed, Md. Mamun Hossain, Abdul Alim-Al-Bari, Md. Rabiul Karim, C. M. Zakaria, Md. Kudrat-E-Zahan, Thermal and Spectral Characterization of Cr (III), Co (II) and Cd (II) Metal Complexes Containing Bis-Imine Novel Schiff Base Ligand Towards Potential Biological Application. Chemical and Biomolecular Engineering. 2017, 2 (1): 41-50.

[22] Xinde Zhu, Chenggang Wang, Zhiping Lu and Yuanlin Dang, Synthesis, characterization and biological activity of the
Schiff base derived from 3, 4-dihydroxybenzaldehyde and thiosemicarbazide, and its complexes with nickel (II) and iron (II). Transition Met. Chem. 1997, 22: 9-13.

[23] Wilfredo Hernández, Juan Paz, Lothar Hennig, Joachim Sieler, Steffen Blaurock, and Lothar Beyer, Synthesis and Characterization of New Palladium (II) Thiosemicarbazone Complexes and Their Cytotoxic Activity against Various Human Tumor Cell Lines. Bioinorganic Chemistry and Applications, 2013, Article ID 524701, p. 12,

[24] B. P. Lever (1984) "Inorganic Electronic Spectroscopy" Elsevier, Amsterdam.

[25] Md. Kudrat-E-Zahan and M. S. Islam, Characterization, and antimicrobial activity of complexes of $\mathrm{Cu}$ (II), Ni (II), Zn (II), $\mathrm{Pb}$ (II), Co (II), Mn (II), and U (VI) containing bidentate Schiff base of [S-methyl-3-(4methoxybenzylidine)dithiocarbazate]," Russian Journal of General Chemistry, 2015, 85 (4): 979-983.

[26] Ikechukwu P. Ejidike and Peter A. Ajibade, Synthesis, Characterization and Biological Studies of Metal (II) Complexes of $(3 E)-3-[(2-\{(E)-[1-(2, \quad 4-D i h y d r o x y p h e n y l)$ ethylidene] amino ethyl) imino]-1-phenylbutan-1-one Schiff Base. Molecules, 2015, 20: 9788-9802. 